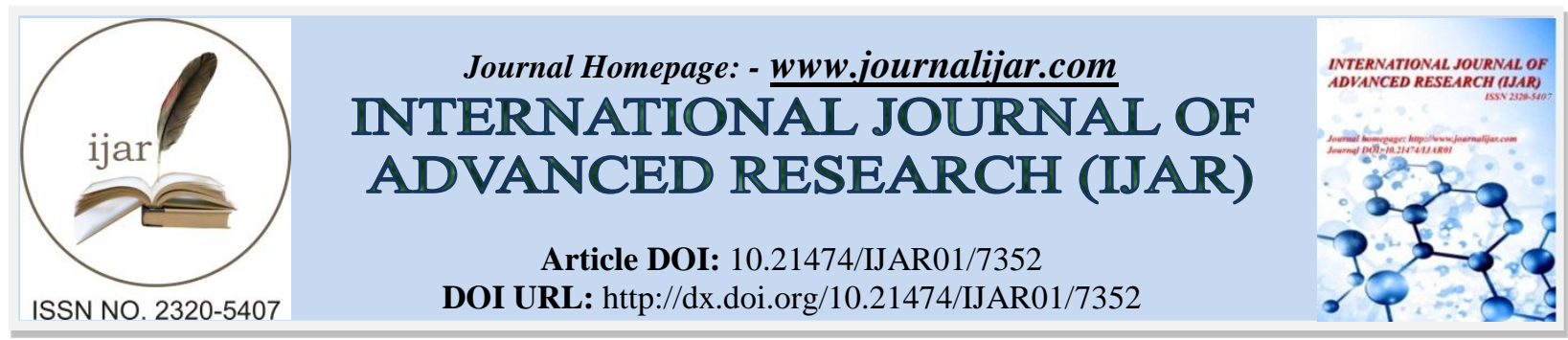

RESEARCH ARTICLE

\title{
PERFORMANCE ANALYSIS OF ACCREDITED COMMUNITY HEALTH CENTRE BASED ON BALANCED SCORECARD WITH STRUCTURAL EQUATION MODELLING IN LUWU TIMUR REGENCY.
}

\author{
Yudi Adnan ${ }^{1}$, Muh. Alwy Arifin ${ }^{2}$ and Anwar Mallongi ${ }^{2}$. \\ 1. Graduate School, Faculty of Public Health, Hasanuddin University. \\ 2. Faculty of Public Health, Hasanuddin University.
}

\section{Manuscript Info}

Manuscript History

Received: 05 May 2018

Final Accepted: 07 June 2018

Published: July 2018

Keywords:-

Accredited, Balanced Scorecard, Community Health Centre, Structural

Equation Modelling.

\begin{abstract}
The study was conducted at Malili, Mangkutana and Kalaena Community Health Centre in Luwu Timur Regency, South Sulawesi, Indonesia. It aims to analyze the influence of Balanced Scorecard method to measure the performance of Accredited Community Health Centre management. The number of research samples is 152 civil servants. Sampling technique is total sampling. Data collection techniques used were observation, interview, documentation, and questionnaire. Data obtained, processed using the help of Smart PLS Software. The statistic method used is Partial Least Square. The results of this study showed that the variables financial perspective, customer perspective, and a learning and growth perspective are significant influential but internal business process perspective is not significant influential. The most dominant influences that can affect the management performance is learning and growth perspective. The result showed that financial perspective, customer perspective, and a learning and growth perspective can explain variety management performance in the mount of $99 \%$ while the remaining $1 \%$ influenced by other variables that aren't known.
\end{abstract}

Copy Right, IJAR, 2018,. All rights reserved.

\section{Introduction:-}

Based on the Strategic Plan of the Ministry of Health 2015-2019, health development program 2015-2019 is Healthy Indonesia with targets that refer to the National Medium-Term Development Plan 2015-2019, one of which is increasing access and quality of basic health care and referral services especially in remote areas, lags and borders in accordance with Law Number 36 Year 2009 on Health that everyone has the right in obtaining safe, quality and affordable health services. ${ }^{1}$

To achieve the national health development goals, a comprehensive range of health, tiered and integrated efforts are being implemented. Based on the Regulation of the Minister of Health Number 75 of 2014 on Community Health Centers, the Center for Public Health is a health care facility that guards up front in the implementation of basic health efforts, especially in the current era of national health insurance.

1 Ministry of Health. (2015b). Ministry of Health Strategic Plan 2015-2019. (Number HK.02.02 /MENKES/52/2015).

Corresponding Author:-Yudi Adnan.

Address:-Graduate School, Faculty of Public Health, Hasanuddin University. 
The Center for Public Health is the Regional Technical Implementation Unit of the Health Office, which serves as a health development center, community-based health promotion center, and first-rate health service center. With the enactment of Law Number 32 Year 2004 regarding Regional Government, the implementation of Community Health Center can't be separated from the responsibility of District Health Office or City.

However, only $24 \%$ of public health centers are capable of carrying out all the components of the diagnosis. ${ }^{2}$ Therefore efforts to improve quality, risk management and patient safety need to be applied in the management of Public Health Centers in providing comprehensive health services to the community through community and private empowerment efforts. ${ }^{3}$

Policies undertaken by the Ministry of Health in an effort to improve the quality of service in first-rate health facilities in particular public health Centers is to issue Regulation of the Minister of Health of the Republic of Indonesia Number 46 Year 2015 About Accreditation Public health center, Primary Clinic, Place Practice Independent Doctor and Place Practice Independent Dentist. It aims to ensure that quality improvement, performance improvement and implementation of risk management are implemented on an ongoing basis in public health centers. Therefore, it is necessary to conduct an assessment by an external party using a standard that is reviewed through a mechanism of accreditation and not just an assessment to obtain an accreditation certificate. Public health centers are required to be accredited on a regular basis at least every three years, as well as accreditation is one of the credential requirements as a first-rate health service facility in cooperation with the Social Security Administering Body. The Social Security Administering Body will cease cooperation partnerships with unaccredited public health centers until $2019 .^{4}$

In this study selected three community health centers each of which is accredited basic, middle and main so that the description of the performance of an accredited public health center can be known. Malili Community Health Center, Mangkutana Community Health Center and Kalaena Community Health Center located in the East Luwu District are selected as research sites because the community health centers in these three sub-districts share a common vision and mission and 24-hour community health center service serve the community but have different population and territory. All these public health centers have also been accredited so that the services of community health centers in these three sub-districts are in accordance with the standards laid out in the Financial Perspective of the Health Office and Social Security Administering Body.

In this study used the Balanced Scorecard (BSC) to measure the performance of community health centers. BSC has been widely adopted by various organizations in the world since the 1990s. Since its introduction by Kaplan and Norton in 1992, the BSC has evolved from a strategic performance evaluation system to an effective instrument for a transformation and strategy implementation, and has become increasingly popular in management practice. Based on several studies, more than $80 \%$ of the world's 1000 best companies have adopted BSC and have expanded into several parts of the world in recent decades. Outside of the business world, BSC has also been successfully adopted by non-profit organizations in government, health, education and charities in recent years. ${ }^{5}$

BSC can provide insight to the head of the public health center about the performance of community health centers. Performance measurement with BSC views business units from four perspectives, namely financial, customer, business process in company perspective, as well as learning and growth process. Through the cause and effect mechanism, the financial perspective becomes the main benchmark described by the operational benchmark in the other three perspectives as the driver (lead indicator).

\section{Method of the Research:-}

The study was conducted at the Malili, Manggarana and Kalaena district health centers of East Luwu. The number of research samples is 152 civil servants. Sampling technique is total sampling. Data collection techniques used

\footnotetext{
${ }^{2}$ Ibid.,

${ }^{3}$ Ministry of Health. (2015a). Regulation of the Minister of Health Number 46 of 2015 on Accreditation of Public Health Centers, Primary Clinics, Self-Practice Physicians and Dentist Self-Establishment Places.

${ }^{4}$ Ibid.,

${ }^{5}$ Zhijun LIN, Zengbiao YU, \& Liqun ZHANG. (2014). Performance outcomes of balanced scorecard application in hospital administration in China. China Economic Review.
} 
were observation, interview, documentation, and questionnaire. Data obtained, processed using the help of Smart PLS Software. The statistic method used is Partial Least Square.

\section{Results and Discussion:-}

\section{Financial Perspective Analysis}

Public health centers as an organizational unit that doesn't focus on profit alone, doesn't mean that finance is not a concern in managing organizations because one indicator of the effectiveness of an organization will begin based on its financial performance. According to Kaplan and Norton, it is explained that Balanced Scorecard financial performance measurement for nonprofit organizations can be seen from fundraising targets as well as administrative and fundraising expenses as a percentage of the overall funds raised.

Malili, Manggarana and Kalaena community health centers prioritize health services to the community, although the service is of concern but researchers in this perspective look at the effectiveness and efficiency of the managed budget. The budget for community health centers has been determined by the District Health Office of East Luwu Regency. Community health centers only implement in accordance with the work plan that has been determined.

Table 1:- Budget Plan and Actual Revenue Expenditure Public health center

\begin{tabular}{|l|l|l|l|l|l|}
\hline \multirow{2}{*}{$\begin{array}{l}\text { Community Health } \\
\text { centers }\end{array}$} & Benchmark & \multicolumn{2}{|l|}{ Year (\%) } & Average (\%) & Information \\
\cline { 3 - 6 } Malili & 2016 & 2017 & & \\
& Economic & 92 & 93 & 92,5 & Economic \\
\cline { 2 - 5 } & Efficiency & 390 & 421 & 405,5 & Not efficient \\
\cline { 2 - 5 } & Effectiveness & 104 & 97 & 100,5 & Effective \\
\hline \multirow{3}{*}{ Mangkutana } & Economic & 98 & 89 & 93,5 & Economic \\
\cline { 2 - 6 } & Efficiency & 129 & 320 & 224,5 & Not efficient \\
\cline { 2 - 6 } & Effectiveness & 120 & 92 & 106 & Effective \\
\hline \multirow{3}{*}{ Kalaena } & Economic & 90 & 90 & 90 & Economic \\
\cline { 2 - 5 } & Efficiency & 220 & 210 & 215 & Not efficient \\
\cline { 2 - 5 } & Effectiveness & 110 & 110 & 88,5 & Effective \\
\hline
\end{tabular}

Source: Primary data processed 2018

From the table above can be seen that the financial performance of local public health centers Malili, Mangkut and Kalaena have a good financial performance. Economic benchmarks and effectiveness of public health centers have been good, but the value of efficiency is still not good.

\section{Customer Perspective Analysis}

Analysis of customer perspective is intended to measure the desire of the customer or the patient so that each customer or patient can feel the best service from health personnel in the community health center. Patient satisfaction is an indicator from this customer perspective. The following presented the Public Satisfaction Index during 2016-2017.

Table 2:- Public Satisfaction Index 2016-2017

\begin{tabular}{|c|c|c|c|c|c|c|}
\hline \multirow[b]{2}{*}{$\begin{array}{l}\text { Community } \\
\text { Health centers }\end{array}$} & \multicolumn{3}{|l|}{ Year 2016} & \multicolumn{3}{|l|}{ Year 2017} \\
\hline & IOS value & $\begin{array}{l}\text { Quality of } \\
\text { Service }\end{array}$ & $\begin{array}{l}\text { Service Unit } \\
\text { Performance }\end{array}$ & IOS value & $\begin{array}{l}\text { Quality of } \\
\text { Service }\end{array}$ & $\begin{array}{l}\text { Service Unit } \\
\text { Performance }\end{array}$ \\
\hline Malili & 78,66 & $\mathrm{~B}$ & Good & 79,02 & $\mathrm{~B}$ & Good \\
\hline Mangkutana & 75,57 & $\mathrm{~B}$ & Good & 76,79 & $\mathrm{~B}$ & Good \\
\hline Kalaena & 81,67 & $\mathrm{~A}$ & Very good & 84,75 & $\mathrm{~A}$ & Very good \\
\hline
\end{tabular}

Source: Primary data processed 2018

Based on the above table on the Satisfaction Index of the Community, where in that year the Value Index of Satisfaction (IOS) Index is increasing. This means that the performance of the community health center service unit is good but it is necessary to always improve the patient's service. 


\section{Analysis of Internal Business Process Perspective:-}

The measurement of internal business process performance aims to measure the performance of services provided by the Malili, Mangkutana and Kalaena health centers. In this study, public health efforts are used to assess the Internal Business Process Perspective of community health centers.

According to the Minister of Health of the Republic of Indonesia number 75 of 2014, health efforts organized by community health centers are grouped into 2 namely essential health programs (mandatory) and health development programs. Compulsory health programs must be organized by each community health center to support the achievement of minimum standards of district health districts. While the health development program is a community health effort whose activities require innovative and/or extensification efforts and service intensification to suit the priority of health problems, the specificity of the work area and the potential resources available in each community health center.

Based on the criteria that have been in the Financial Perspective on the performance report of the health center, the performance of health service coverage is grouped into three, namely: Group I (good performance): Achievement rate $\geq 91 \%$, Group II (sufficient performance): Achievement rate $81-90 \%$, and Group III (less performance): Achievement rate $\leq 80 \%$. Therefore, in Table 4.13 below the researchers present some data on the percentage of compulsory health care coverage and development program at Malili, Manggarana and Malili public health centers in 2016 and 2017.

Table 3:- Coverage of Mandatory Health Efforts and Development Programs at Malili, Manggarana and Malili Health Centers In 2016 and 2017

\begin{tabular}{|c|c|c|c|c|c|c|}
\hline \multirow{3}{*}{ Mandatory Health Efforts } & \multicolumn{6}{|c|}{ Percentage of program achievements } \\
\hline & \multicolumn{2}{|c|}{$\begin{array}{l}\text { Malili public } \\
\text { health center }\end{array}$} & \multicolumn{2}{|c|}{$\begin{array}{l}\text { Manggungana public } \\
\text { health center }\end{array}$} & \multicolumn{2}{|c|}{$\begin{array}{l}\text { Kalaena Community } \\
\text { Health Center }\end{array}$} \\
\hline & 2016 & 2017 & 2016 & 2017 & 2016 & 2017 \\
\hline Health Promotion & $80,12 \%$ & $80,65 \%$ & $80,33 \%$ & $81,12 \%$ & $88,01 \%$ & $89,81 \%$ \\
\hline II. Environmental Health & $81,41 \%$ & $82,32 \%$ & $81,53 \%$ & $81,99 \%$ & $80,32 \%$ & $76,46 \%$ \\
\hline $\begin{array}{l}\text { III. Maternal Child Health and } \\
\text { Family Planning }\end{array}$ & $78,36 \%$ & $78,77 \%$ & $84,12 \%$ & $85,00 \%$ & $83,86 \%$ & $90,51 \%$ \\
\hline $\begin{array}{l}\text { IV. Efforts to improve people's } \\
\text { nutrition }\end{array}$ & $91,68 \%$ & $92,11 \%$ & $85,12 \%$ & $87,39 \%$ & $85,79 \%$ & $82,69 \%$ \\
\hline $\begin{array}{ll}\text { V. Prevention and Control of } \\
\text { Infectious Diseases }\end{array}$ & $89,83 \%$ & $89,12 \%$ & $87,29 \%$ & $87,23 \%$ & $86,96 \%$ & $89,45 \%$ \\
\hline $\begin{array}{ll}\text { VI. } & \text { Treatment Efforts } \\
\end{array}$ & $90,25 \%$ & $91,50 \%$ & $87,90 \%$ & $90,19 \%$ & $80,16 \%$ & $80,53 \%$ \\
\hline VII. Health development & $72,63 \%$ & $75,44 \%$ & $74,11 \%$ & $78,00 \%$ & $81,50 \%$ & $85,92 \%$ \\
\hline
\end{tabular}

Source: Performance Report Public health center

From Table 4.13, it appears that the average performance of compulsory health programs and development at Malili Community Health Center in 2016 ranged between $72.63 \%$ to $91.68 \%$ with an average of $83.47 \%$ (enough), while in the year 2017 ranged from $75.44 \%$ to $92.11 \%$ with an average value of $84.27 \%$ (enough). Achievements of compulsory health and development programs at the Manggarana Community Health Center in 2016 range from $74.11 \%$ to $87.90 \%$ with an average of $82.91 \%$ (enough), while in 2017 it ranges from $78 \%$ to $90.19 \%$ with an average score of $84.42 \%$ (sufficient). Meanwhile, the achievement of compulsory health program and development program at Kalaena Public Health Center in 2016 ranged between $80.16 \%$ to $88.01 \%$ with an average value of $83.80 \%$ (enough), while in 2017 it ranged between $76,46 \%$ to $90.51 \%$ with an average value of $85.05 \%$ (enough). From the table above also shows an increase in the Coverage of Mandatory Health Efforts and Development Program from year to year in the Malili, Mangkutana and Kalaena community health centers.

In addition, this study also shows that employee appraisal of the Business Process Internal Process Perspective The public health center is in good category. Here are the descriptive statistics of employee answers to the Perspective of Business Internal Processes. 
Table 4:- Descriptive Statistics of Employees' Answers (Business Process Internal Perspective)

\begin{tabular}{|l|l|l|l|l|}
\hline & Min & Max & Mean & Std. Deviation Statistic \\
\hline X21 & 2,00 & 4,00 & 3,2829 &, 59153 \\
\hline X22 & 2,00 & 4,00 & 3,3355 &, 57479 \\
\hline X23 & 2,00 & 4,00 & 3,3026 &, 56427 \\
\hline X24 & 2,00 & 4,00 & 3,2961 &, 57358 \\
\hline X25 & 2,00 & 4,00 & 3,3092 &, 56655 \\
\hline X26 & 2,00 & 4,00 & 3,0066 &, 37287 \\
\hline
\end{tabular}

Source: Primary data processed 2018

Based on the results of descriptive statistical analysis shows that from 152 respondents the score of respondents' answers about service performance is in the range 3 and 4 with an average score of answers 3 . 3. Therefore, means the performance of services provided by the Malili public health center, Mangkutana and Kalaena are considered to be quite high, so only need to maintain the quality of service and service improvement to provide satisfaction for customers.

\section{Growth and Learning Perspective Analysis}

The learning and growth perspective aims to describe the organization's efforts in maintaining the organization's intangible assets, which are sometimes ignored by the organization. Employees play an important role for the organization in generating profit and non profit, because either directly or indirectly will determine the smoothness of the entire process that exist within the organization and the determination of the success of the other three perspectives.

Table 5:- Descriptive Statistics of Employees' Answers (Growth and Learning Perspective)

\begin{tabular}{|l|l|l|l|l|}
\hline & Min & Max & Mean & Std. Deviation Statistic \\
\hline X41 & 2,00 & 4,00 & 3,3289 &, 61737 \\
\hline X42 & 2,00 & 4,00 & 3,3224 &, 61549 \\
\hline X43 & 2,00 & 4,00 & 3,3224 &, 61549 \\
\hline X44 & 2,00 & 4,00 & 3,3224 &, 61549 \\
\hline X45 & 2,00 & 4,00 & 3,2763 &, 61113 \\
\hline X46 & 2,00 & 4,00 & 3,3026 &, 62018 \\
\hline X47 & 2,00 & 4,00 & 3,3026 &, 60941 \\
\hline X48 & 2,00 & 4,00 & 3,3092 &, 60059 \\
\hline X49 & 2,00 & 4,00 & 3,2763 &, 60019 \\
\hline X410 & 2,00 & 4,00 & 3,3026 &, 60941 \\
\hline
\end{tabular}

Source: Primary data processed 2018

Based on the results of statistical analysis descriptive seen that of 152 respondents, the score of respondents' answers about employee satisfaction is in the range of 2-4 with an average score of answers 3. 3. Therefore, means that health center employees are quite satisfied with the treatment given by the Leader, so only need to maintain employee satisfaction and improvement of learning in order to provide satisfaction for employees.

The higher the level of training, the ability of employees in the service the better also. The results of the training level data observation at the Malili, Mangkutana and Kalaena community health centers are as follows:

Table 6:- Training Level Local community health centers Malili, Mangkutana and Kalaena

\begin{tabular}{|l|l|l|l|}
\hline Community Health centers & Year & Number of civil servants & $\begin{array}{l}\text { The Number that Attend } \\
\text { Training }\end{array}$ \\
\hline \multirow{3}{*}{ Malili } & 2016 & 65 & 10 \\
\cline { 2 - 4 } & 2017 & 68 & 7 \\
\hline \multirow{2}{*}{ Mangkutana } & 2016 & 53 & 9 \\
\cline { 2 - 4 } & 2017 & 54 & 9 \\
\hline Kalaena & 2016 & 34 & 6 \\
\cline { 2 - 4 } & 2017 & 34 & 6 \\
\hline
\end{tabular}

Source: Primary data processed 2018 


\section{Test Reliability:-}

In this study a variable is said to be quite reliable when the variable has a composite reliability value greater than 0.7 and has an AVE value greater than 0.5. Here are the results of testing the reliability of each latent variable with the help of SmartPLS software.

Table 7:- Testing End Reliability

\begin{tabular}{|l|l|l|l|l|l|}
\hline & $\begin{array}{l}\text { Cronbach's } \\
\text { Alpha }\end{array}$ & $\begin{array}{l}\text { rho_- } \\
\text { A }\end{array}$ & $\begin{array}{l}\text { Composite } \\
\text { Reliability }\end{array}$ & $\begin{array}{l}\text { Average Variance } \\
\text { Extracted }\end{array}$ & $\begin{array}{l}\text { R } \\
\text { Squa } \\
\text { re }\end{array}$ \\
\hline $\begin{array}{l}\text { Management Performance Community } \\
\text { Health centers (Y) }\end{array}$ & 0,978 & $\begin{array}{l}0,97 \\
8\end{array}$ & 0,981 & 0,835 & 0,99 \\
\hline Financial Perspective (X1) & 0,956 & $\begin{array}{l}0,96 \\
0\end{array}$ & 0,964 & 0,794 & \\
\hline Patient Perspective (X3) & 0,969 & $\begin{array}{l}0,97 \\
0\end{array}$ & 0,975 & 0,867 & 0,859 \\
\hline Internal Business Process Perspective (X2) & 0,959 & $\begin{array}{l}0,95 \\
9\end{array}$ & 0,968 & 0,939 & \\
\hline Growth and Learning Perspective (X4) & 0,979 & 0,97 & 0,981 & & \\
\hline
\end{tabular}

Source: Output smart PLS

Based on the results of the above table, it can be concluded that all variables have AVE $>0.5$ and all $\rho c \geq 0.7$ as well as endogenous latent variables. Thus, it can be concluded that the indicators used in the variable already has good reliability or is able to measure the construct. $\mathrm{R}$ square shows that the variables are able to explain the diversity of Performance Management Center of public health (Y) of $99 \%$ while the remaining 1\% is explained by other variables.

\section{Evaluation of Measurement Model (Outer Model)}

Figure 1:- Output PLS Algorithm

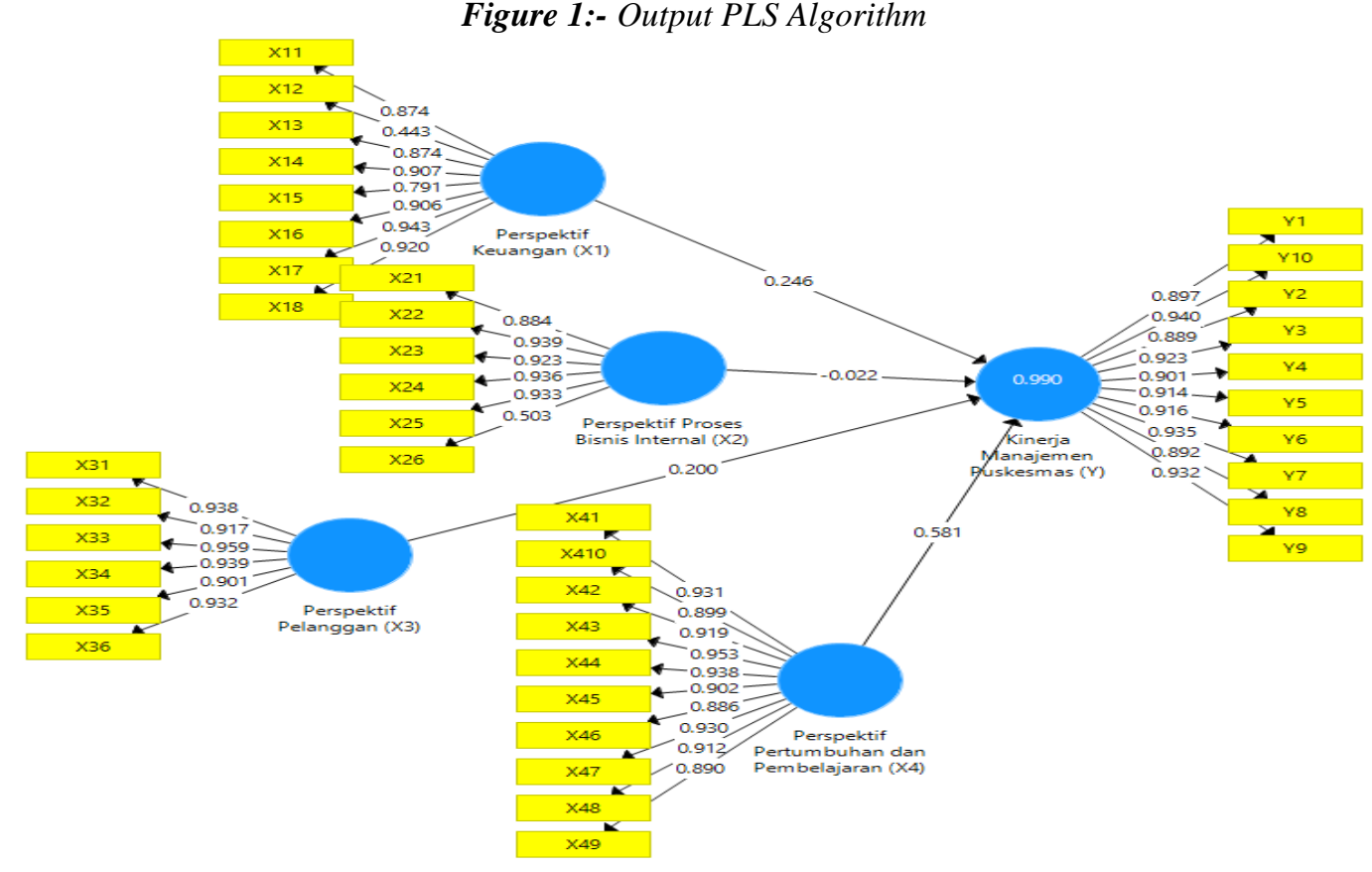

Based on the results of the table above, it shows that there are still some latent whose AVE value is $<0.5$, CUSTOMER PERSPECTIVE and PERSPECTIVE GROWTH AND LEARNING means that there are still indicators that need to be deleted. Based on the structural equations illustrated by SmartPLS software assistance, an 
indicator is found that has a value of <0.7. These indicators are FINANCIAL PERSPECTIVE (X12) and PERSPECTIVE INTERNAL BUSINESS PROCESS (X26)

Figure 2:- Output Bootstoping PLS

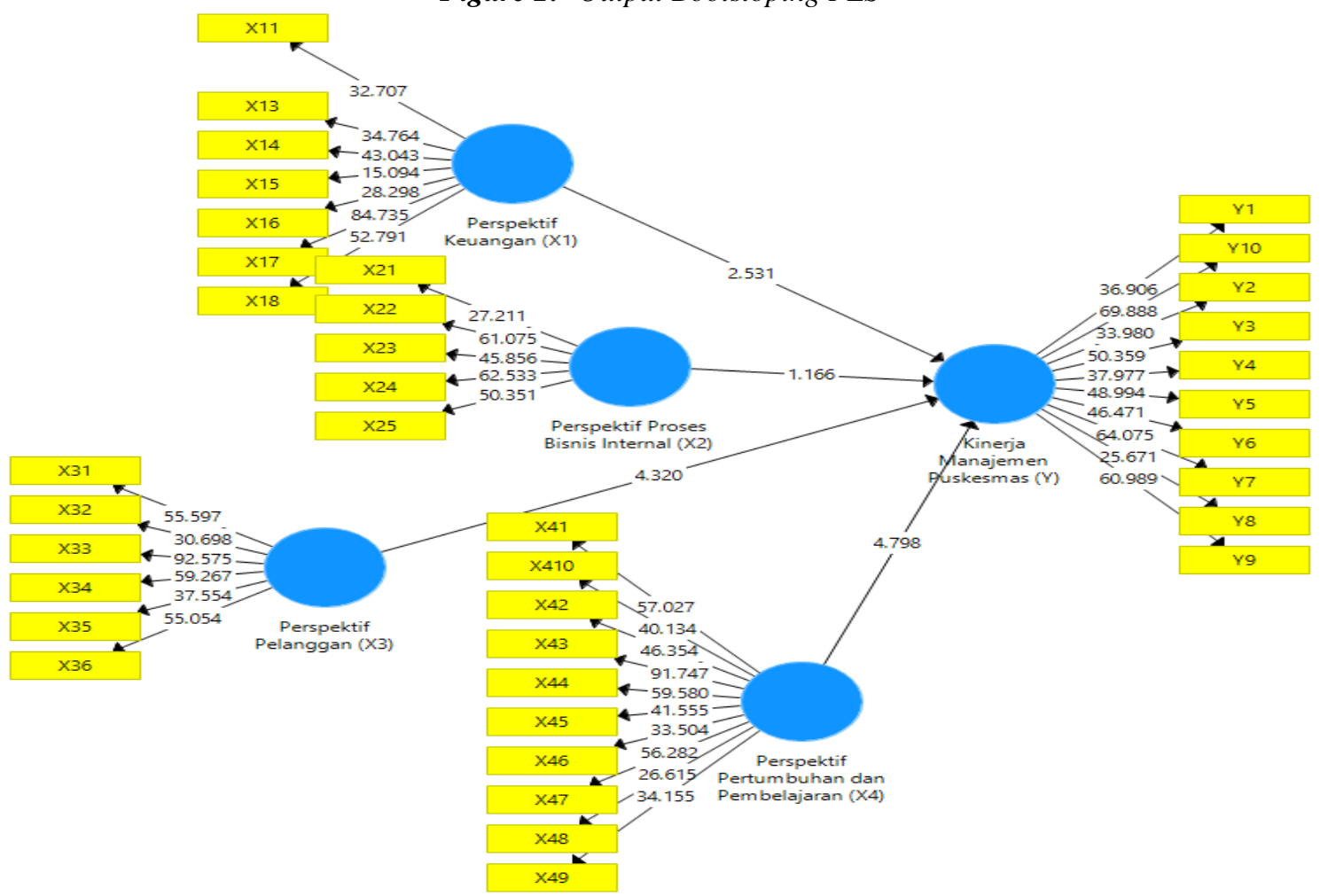

Source: Output smartPLS

By using $\alpha$ of $5 \%$ with $t$ table equal to 1,97623 if $t$ count bigger than $t$ table, hence mean that data have effect. From the results of data processing, it is known that all indicators have an influence on latent variables. If $\mathrm{t}$-statistics> $\mathrm{t}$ table (1.97623) then the meaning is valid and significant data. $\mathrm{T}$ table obtained by using the formula: $\mathrm{D}=\mathrm{n}-\mathrm{k}$; where $\mathrm{n}$ is the number of samples and $\mathrm{k}$ is the number of variables used.

\section{Evaluation of Structural Model (Inner Model) (Running Bootstrapping 152 Samples)}

The structural model can be evaluated by looking at the value of R2 in the endogenous variable and the path coefficient parameter. Here the hypothesis raised in this study are:

Table 8:- Hypothesis testing

\begin{tabular}{|c|c|c|c|c|c|c|}
\hline & $\begin{array}{l}\text { Original } \\
\text { Sample } \\
\text { (O) }\end{array}$ & $\begin{array}{l}\text { Sample } \\
\text { Mean } \\
\text { (M) }\end{array}$ & (STDEV) & $\begin{array}{lrl}\text { T } & \text { Statistik } \\
\text { O/STDEV } \mid\end{array}$ & P Values & Conclusion \\
\hline $\begin{array}{l}\text { Financial Perspective }(\mathrm{X} 1) \\
->\quad \text { Performance } \\
\text { Management Center Of } \\
\text { Community Health }(\mathrm{Y})\end{array}$ & 0,246 & 0,255 & 0,097 & 2,531 & 0,012 & Significant \\
\hline $\begin{array}{l}\text { Customer } \quad \text { Perspective } \\
\text { (X3) -> Performance } \\
\text { Management Center Of } \\
\text { Community Health (Y) }\end{array}$ & 0,194 & 0,196 & 0,045 & 4,320 & 0,000 & Significant \\
\hline $\begin{array}{ll}\text { Perspective } & \text { Internal } \\
\text { Business Process } & \text { (X2) }-> \\
\text { Performance } & \text { Of } \\
\text { Community Health Center }\end{array}$ & $-0,019$ & $-0,019$ & 0,017 & 1,166 & 0,244 & Not significant \\
\hline
\end{tabular}




\begin{tabular}{|c|c|c|c|c|c|c|}
\hline$(\mathrm{Y})$ & & & & & & \\
\hline $\begin{array}{lll}\text { Perspective } & \text { Growth } & \text { And } \\
\text { Learning } \quad \text { (X4) } & -> \\
\text { Performance } & \text { Of } \\
\text { Community } & \text { Health Center } \\
\text { (Y) }\end{array}$ & 0,584 & 0,573 & 0,122 & 4,798 & 0,000 & Significant \\
\hline
\end{tabular}

Source: Output smart PLS

H1: Perspective Internal Business Process has no effect on Performance Of Community Health Center Management. The result of T test on the PLS output shows the value of $t$-count $(1.166)<t$-table $(1,97623)$ means the hypothesis is accepted. This means that the Internal Business Process has no effect on Public Health. The results of this study are in accordance with the theories that have been developed by Kaplan and Norton (2000).

H2: Financial Perspectives have an influence on the Performance Of People's Health Center Public Health Management Performance. The result of T test on the PLS output shows the value of t-count $(2,531)>t$-table $(1,97623)$ meaning the null hypothesis is rejected. This means that Financial Perspective significantly influences the Performance Management Center Of Community Health. The results of this study are in accordance with the theories that have been developed by Kaplan and Norton (2000).

H3: Customer's Perspective has an influence on the negative Community Health Center Public Performance. The result of T test on the PLS output shows the value of $t$-count $(4,320)>t$-table $(1,97623)$ meaning the null hypothesis is rejected. This means that Customer Perspective has a significant effect on Performance Of Community Health Center Management. The results of this study are supported by research conducted by Sulasni (2014).

H4: Growth And Learning Perspectives have an influence on the positive Public Health Management Performance. The result of $\mathrm{T}$ test on the PLS output shows the value of $\mathrm{t}$-count $(4,798)>t$-table $(1,97623)$ meaning the hypothesis is rejected. This means that Perspective Growth And Learning have a significant effect on Performance Of Community Health Center Management Performance. The results of this study are in accordance with the theory that has been developed by Kaplan and Norton (2000).

\section{Conclusions:-}

The results showed that financial perspective, customer perspective, and learning and growth perspective significantly influence, while internal business process perspective has no effect on management performance. The dominant variables affecting the management performance are Learning and Growth Perspective. The results show that the financial perspective, customer perspective, and learning and growth perspective can explain the diversity of management performance by $99 \%$ while the remaining $1 \%$ is influenced by other unknown variables.

\section{References:-}

1. Alamsyah, D. (2011). Manajemen Pelayanan Kesehatan. Yogyakarta: Nuha Medika.

2. Artini, I. W. S., I.P. Ganda Wijaya. (2016). Hubungan Penerapan Manajemen Pusat kesehatan masyarakat dan Komitmen Kerja dengan Mutu Pelayanan Pengobatan di Pusat kesehatan masyarakat Kabupaten Karangasem, Bali. Public Health and Preventive Medicine Archieve, 4(1).

3. Azwar, A. (2010). Pengantar Administrasi Kesehatan (Edisi 3). Tangerang: Binarupa Aksara Publiher.

4. Bustami. (2011). Penjaminan Mutu Pelayanan Kesehatan \& Akseptabilitasnya. Jakarta: Erlangga.

5. Ch. Platis, P. Reklitis, \& S. Zimeras. (2014). Relation between job satisfaction and job performance in healthcare services. Procedia - Social and Behavioral Sciences, 175(2015).

6. Darwanto, H. (2009). Balanced Scorecard untuk Organisasi Pemerintah. Retrieved 1 April 2018, 2018, from https://www.bappenas.go.id/id/data-dan-informasi-utama/makalah/artikel-majalah-perencanaan/edisi-33-tahun2003/balanced-scorecard-untuk-organisasi-pemerintah---oleh-herry-darwanto/

7. Devani, V. (2016). Pengukuran Kinerja Perpustakaan Dengan Pendekatan Balanced Scorecard. Jurnal Ilmiah Teknik Industri, 15(1).

8. Febriana, Y. (2012). Kinerja Pusat kesehatan masyarakat Pahandut Kota Palangkaraya dengan Analisis Dasar Aspek-Aspek Balanced Scorecard.

9. Febriyanti, D. (2016). Analisis Kinerja Rumah Sakit dengan Pendekatan Balanced Scorecard. Universitas Sanata Dharma, Yogyakarta. 
10. Heather K. Spence Lascchier, \& Roberta Fida. (2015). Linking Nurses' Perceptions of Patient Care Quality to Job Satisfaction. The Journal of Nursing Administration, 45(5).

11. Hongda Gao, H. C., Jun Feng, Xianjing Qin, Xuan Wang, Shenglin Liang, Jinmin Zhao, Qiming Feng. (2017). Balanced scorecard-based performance evaluation of Chinese county hospitals in underdeveloped areas. Journal of International Medical Research, $O(0)$.

12. Josep Bisbe, \& Joan Barrubes. (2012). The Balanced Scorecard as a Management Tool for Assessing and Monitoring Strategy Implementation in Health Care Organizations. Elsevier espana, 65(10).

13. Kabupaten Luwu Timur. (2017). 7 Pusat kesehatan masyarakat Luwu Timur, lolos Akreditasi Kementerian kesehatan RI. Retrieved 6 Februari, 2018, from http://www.luwutimurkab.go.id

14. Kaplan, R. S., \& Norton, D. P. (2000). MeneraPerspektif Keuanganan Strategi menjadi Aksi Balanced Scorecard. Jakarta: Erlangga.

15. Kementerian Kesehatan. (2014). Peraturan Menteri Kesehatan No. 75 tentang Pusat Kesehatan Masyarakat.

16. Kementerian Kesehatan. (2015a). Peraturan Menteri Kesehatan No. 46 Tahun 2015 Tentang Akreditasi Pusat kesehatan masyarakat, Klinik Pratama, Tempat Praktik Mandiri Dokter, dan Tempat Praktik Mandiri Dokter Gigi.

17. Kementerian Kesehatan. (2015b). Rencana Strategis Kementerian Kesehatan Tahun 2015-2019. (No. HK.02.02/MENKES/52/2015).

18. Kementerian Kesehatan. (2017). Data dan Informasi Profil Kesehatan Indonesia 2016.

19. Ketut Mahardika, \& Supadmi, N. L. (2014). Analisis Komparatif Kinerja Pusat kesehatan masyarakat Denpasar Selatan Dan Denpasar Timur Dengan Menggunakan Metode Balanced Scorecard.

20. Kurubaran Ganasegeran, Wilson Perianayagam, Rizal AbdulManaf, Saad Ahmed Ali Jadoo, \& Sami Abdo Radman Al-Dubai. (2014). Patient Satisfaction in Malaysia's Busiest Outpatient Medical Care. Hindawi Publishing Corporation The Scientific World Journal, 2015. 